DOI: $10.17516 / 1997-1370-0504$

УДК 1(091), 8(82)

\title{
Socratic Dialogue as Kairotic Logos
}

\section{Elena V. Alymova*}

Saint Petersburg State University

St. Petersburg, Russian Federation

Received 17.12.2018, received in revised form 16.10.2019, accepted 18.11.2019

\begin{abstract}
The article is dedicated to the Soctatic dialogue as a genre of Ancient philosophical literature, represented by the so-called Socratics. The masterpieces of this type of composition are the dialogues of Plato. A special feature of the following research is that the Socratic dialogue is being treated in the light of one of the most intricate concepts of Ancient Philosophy - kairos. Its meaning is especially obscure since being present in various contexts such as poetry and prose compositions it has no special definition. In the article the concept of kairos is being reconsidered. This new interpretation is based on the original affinity of the kairos with the art of weaving, which, in its turn, is considered as paradigm of the art of interweaving of logoi and dramatic composition.
\end{abstract}

Keywords: kairos, logos, Socratic dialogue, philosophical dialogue, Socratics, art of weaving, Plato.

The current research is fulfilled within the framework of the project: Russian Foundation of Fundamental Research No. 17 - 03 - 00616a: Socratic Schools as Phenomenon of Ancient Philosophy and Culture. 2017-2019.

Research area: philosophy.

Citation: Alymova, E.V. (2020). Socratic dialogue as kairotic logos. J. Sib. Fed. Univ. Humanit. Soc. Sci., 13(8), 1238-1249. DOI: 10.17516/1997-1370-0504.

(C) Siberian Federal University. All rights reserved

* Corresponding author E-mail address: ealymova@yandex.ru 


\section{Introduction}

We have already dealt with such concepts as logos, mythos and chronos (Alymova, 2008: 8-28; Alymova, 2017a: 21). Hereby we continue our line of research and would like to turn to one of the most enigmatic and provocative concepts of Ancient Philosophy - kairos. It is a complex concept, not easily reduced to a simple formula. The meaning of kairos is especially obscure since being present in various contexts such as poetry (e.g. the Victory Odes of Pindar or dramatic poetry) and prose compositions (e.g. of Gorgias, Aeschines Socratucus, Plato and the authors of the Corpus Hippocraticum) it has no special definition within these contexts. At the same time the range of interpretations of kairos is rather vast: we find numerous testimonies not only in philosophical explications but also in translations, e.g. due measure, wise moderation, proportion, profit, possibility, circumstances, crisis, aim, season, timing, "srok"/"svoi chas" ("the day of destiny") (M. Gasparov), "pora" ("high time") (V. Bibikhin, A. Akhutin) and last but not least - opportunity. The list of interpretations cited above makes it evident that two significations prevail - time and opportunity. Kairos as opportunity retains a close relation with the etymon, which at first sight fixes the original sense of the word - porta (door, entrance) or portus (port) (nowadays another version to render the meaning has become current - the window of opportunities). It is bizarre how the senses of opportunity and time - not to mention measure - coincide in one and the same signification. No doubts, certain efforts might be exerted (and they were exerted) to reconcile all the interpretations mentioned above. But the problem is that such unifying interpretations are founded on preconception that kairos is primarily connected with time and timing. The relevant sources for such interpretation are following: as a designation for the moment in which the situation irreversibly turns to the better or worse, the word kairos started to be used approximately from the second half of the $\mathrm{Vth} \mathrm{BC}$, and in this connection the Corpus Hippocraticum and the famous sculpture of Lisippus of Sicyon should be mentioned. As for the Corpus Hippocrat- icum, the following quotation is traditionally

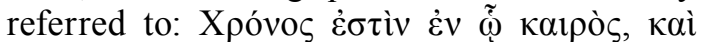

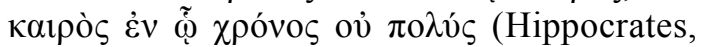
1923: 312) (Time/Chronos, is that, in which there is kairos, and kairos, in which there is chronos, is not long [The translation is ours E.A.]). It is remarkable that time as chronos is being opposed to time as kairos (which is, as a matter of fact, measured as "being not long"). On the other hand, the sculpture of Lisippus has become the visual paradigm of Kairos as a crucial and decisive moment.

The interpretation of kairos as time/moment impacted the Christian conception of kairos as it is proposed, for example, by Paul Tillich in two works with the same title - "Kairos" (1922 and 1948), where kairos is interpreted as the moment (and in this sense it is being conceived as timeless) when and where the human existence opens itself to the eternity (being-towards-eternity).

Significant concepts, which constitute the arsenal of philosophical vocabulary, have to be reconsidered now and then in order not to become an automatically used vocabulary of shoptalk. The concept of kairos should not be exception.

To analyze the concept of kairos is not an end in itself in the framework of our article. In our paper we defend the interpretation based on the original affinity of the kairos with the art of weaving, which we consider as paradigm of the art of interweaving of logoi and even of the art of dialectics and dramatic composition as they are represented in Plato's dialogues.

\section{Materials and Methods}

We propose to start with specific texts and even objects to sharpen the meaning of the concept of kairos. The different significances of the Greek word kairos have been recently investigated, among others, by Monique Trédé-Boulmer (Trédé-Boulmer, 1992). Monique Trédé-Boulmer argues that the meaning "the opportune moment" puts restrictions on the concept of kairos, drastically reducing its semantic potential. Still we are substantially influenced by another French scholar - Bernard Gallet - and his opus "Recherches sur Kairos et l'ambiguïté dans la 
poesie de Pindar" (Gallet, 1990). He studies the poetry of Pindar whose poetic vocabulary privileges the word kairos. To this interpretation adheres Michail Jampolsky (Jampolsky, 2007: 50 - 59).

While the widely accepted translations are all derived from the preconceived idea of time, Bernard Gallet argues that this is not the case in Pindars' Odes. He (as well as M. Trédé-Boulmer) follows the intuition of Richard Onians. R. Onians was the first to suggest the affinity between two words kairos and kairos (accentuated with circumflex over the diphthong) - "The Origin of European thought about the body, the mind, the soul, the world, time and fate" (Onians, 1951). This circumflexed form did not really exist in Greek - this word appeared in numerous scholia to Homer (namely to a line from the VIIth book of the Odyssey). R. Onians put forward a brilliant conjecture though unfortunately left it aside without deducing any conclusions. He surmised that kairos belonged to the art of weaving: that is, according to R. Onian's idea, kairos is whether the warp or has something to do with separating of threads. Still he himself followed another way corroborating the interpretation of kairos as opportunity.

Having presented a synopsis of interpretations we turn to the relevant sources.

Reconsidering kairós. All the roads lead us to Homer. Homer does not know (or at least does not use) the word kairos. Instead he uses the adjective kairios and the neuter of it with the article - to kairion. The earliest evidence of the word kairos in this form gives Hesiod (Works and Days). Here we have one mention (v. 694):

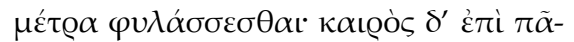

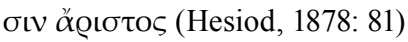

One should be moderate. And kairos in everything is the best

[The translation is ours. $-E . A$.].

And here arises a problem - how should we connect the kairos interpreted in this way with the line in Homer's Odyssey (the only line in this poem where the Poet uses a word of the root in question), which serves a point (or rather - the point) of reference (Od. VII, 107):

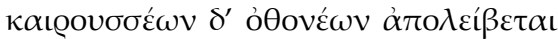

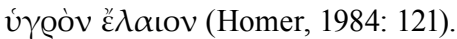

In order to retain the context we quote the translation [translation of Homer here and elsewhere of A.T. Murray] of it at some length:

And others weave webs, or, as they sit, twirl the yarn, like unto the leaves of a tall poplar tree; and from the closely-woven linen the soft olive oil drips down. For as the Phaeacian men are skilled above all others in speeding a swift ship upon the sea, so are the women / cunning workers at the loom, for Athene has given to them above all others skill in fair handiwork, and an understanding heart (Homer, 1919a: 239, 241).

This passage was vastly commented on by the scholars of the Late Antiquity because

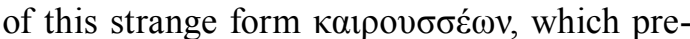

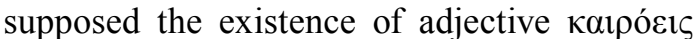
(this form is but hypothetical). Hereby we are referred to the art of weaving.

We shall adduce another evidence, following the way blazed by Bernard Gallet (Gallet, 1990). It will be the Dendra panoply or Dendra armor. It is an example of a Mycenaean-era panoply (full-body armor) (in the collection the Napflion Archeological museum) made of bronze plates, discovered in 1960 in the village of Dendra in the Argolid (the region of the Peloponnese). The Dendra panoply is a sort of scale armor consisting of many individual small, or not very small as in our case, scales (plates) of various shapes attached to each other and to a backing of cloth or leather in overlapping rows. It represents the oldest form of metal body armor, which was widely used throughout the eastern Mediterranean. It dates to the end of the fifteenth century BC. The Dendra Panoply consists of fifteen separate pieces of bronze sheet, held together with leather thongs or leather cords. It protected the wearer from neck to knees. The panoply 
includes breast-plates and back-plates, greaves (leg-protectors) and arm-guards. We shall not go into a detailed description, but rather draw attention to the points of interest concerning our arguments.

With this panoply we intrude into the reign of the art of war. So it seems natural to evoke Homer's Iliad. It provides a context for the adjective kairios and for the neuter of it with the article - to kairion.

Let us cite some relevant contexts from Homer's Iliad (Il. IV, 183-187):

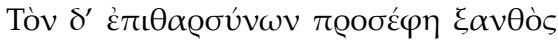

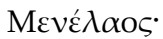

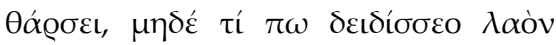
A $\chi \alpha \iota \tilde{\omega} v^{\circ}$

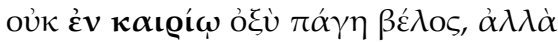
$\pi \alpha ́$ @ot $\theta \varepsilon v$

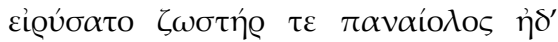

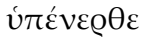

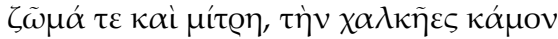
ävọes (Homer, 1910: 71).

But fair-haired Menelaus spake and heartened him, saying: "Be thou of good cheer, neither affright in any wise the host of the Achaeans. Not in a fatal spot hath the shaft been fixed; ere that my flashing belt stayed it, and the kilt beneath, and the taslet that the coppersmiths fashioned" (Homer, 192425a: 167).

Another example (Il. VIII, 324 - 328):

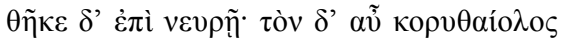

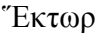

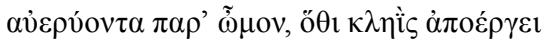

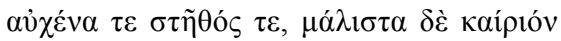
$\dot{\varepsilon} \sigma \tau 1$,

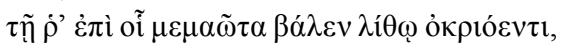

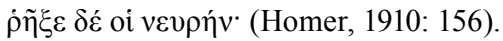

(Now Teucer) had drawn forth from the quiver a bitter arrow, and laid it upon the string, but even as he was drawing it back Hector of the flashing helm smote him beside the shoulder where the collar-bone parts the neck and the breast, where is the deadliest spot (Homer, 1924-25a: 363).
The spot which is called kaípıov, means a vital point and to hit it would mean to cause death.

And here comes forth the following question: how to connect the meanings of opportunity and death, that is the question of how

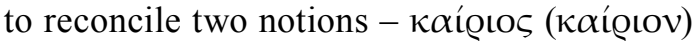

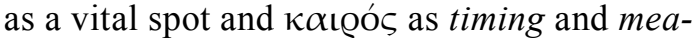
sure.

At this point we have to turn to the verse of the Odyssey (Od. VII, 107), mentioned above, which recounts the process of making fabrics

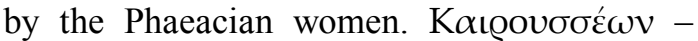
plural genitive of $\kappa \alpha$ เ@ócเ $\varsigma$, this is an adjective with the meaning of a thing defined as possessing in great measure the quality determined by this adjective. For example: $\chi \alpha$ oícı $\varsigma$ - graceful

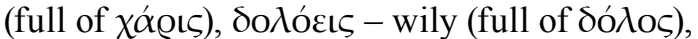

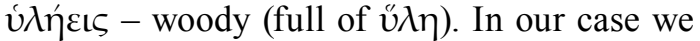
are bound to suppose that a thing defined as

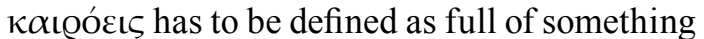

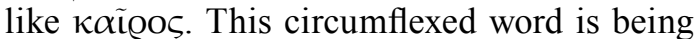
reconstructed on the basis of Homer's $\kappa \alpha \mathrm{L}-$

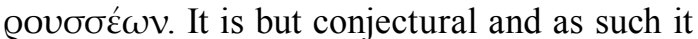
appears in the scholia and commentaries to the epic of Homer. According to the reconstruction, we restore the verb $-{ }^{*} \kappa \alpha$ Łoó $\omega$ (supply with $\kappa \alpha$ ĩoos). A context within the limits of which we gain the word kaĩoos is the context of the art of weaving.

We have already put the question, how to reconcile the meanings of opportunity, vulnerable spot and due measure. An immediate transition from one meaning to another looks strange. We admit, it is easy to reinterpret this transition post factum. But the question about the original meaning, the conceptual core of the notions opportunity, vulnerable spot and due measure still exists. The interpretation is aggravated by a reconstruction of a technical meaning of кaĩoos, in the sense of the art of weaving.

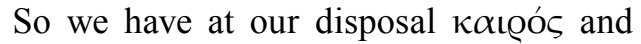
кaĩoos. We have to draw a line between these two terms. Let us turn to the dictionar-

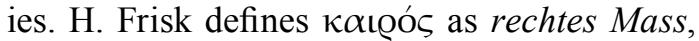
Zeitpunkt, Gelegenheit (due measure, right moment, opportunity) (Frisk, 1960: 755) and

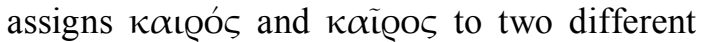
entries. P. Chantraine makes a point of these 
two different meanings but in the entry dedicated to kaĩoos he says: "mais le mot rend

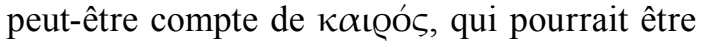
un employ figuré ("le point exact, le point de rencontre, le nœud?") avec changement d'ac-

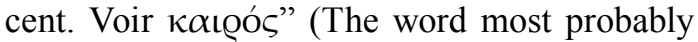

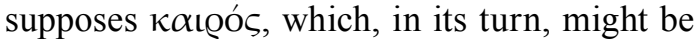
used figuratively ("the crucial point, the point of junction, the knot?") with a different ac-

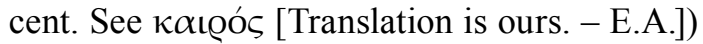
(Chantraine, 1968-1980: 480).

A vulnerable spot means the most appropriate spot to penetrate, where a weapon could hit effectively. To hit such a spot a solder should be appropriately trained and versed in such

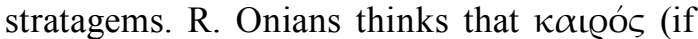
such a word existed in the poems of Homer) would signify the target, which was to be hit by the archers while they were training. And this target looked, according to R. Onians and Homer (as interpreted by R. Onians), as an aperture or hole in the blade of a battle-ax (ó $\pi \dot{\varepsilon}-$ $\lambda \varepsilon \kappa \cup \varsigma)$. An image of such a battle-ax and the act of shooting is represented in the Odyssey, XIX, 573-576:

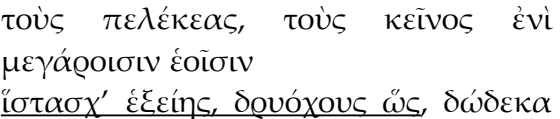
$\pi \alpha \dot{v} \nu \tau \alpha \varsigma^{\circ}$

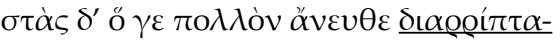

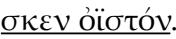

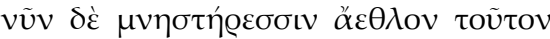

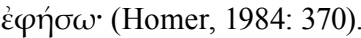

Those axes which he was wont to set up in line in his halls, like props of a ship that is building, twelve in all, and he would stand afar off and shoot an arrow through them. Now then I shall set this contest before the wooers (Homer, 1919b: 269, 271)

and in the Odyssey, XXI, 120-123:

$\pi \rho \tilde{\omega} \tau \mathrm{o} \nu \mu \dot{\varepsilon} \nu \pi \varepsilon \lambda \varepsilon \dot{\varepsilon} \kappa \varepsilon \alpha \varsigma \sigma \tau \tilde{\eta} \sigma \varepsilon v, \delta$ iò $\tau \alpha \dot{\varphi} \varphi \rho \circ \nu$

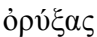

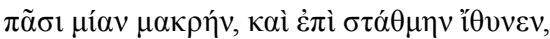

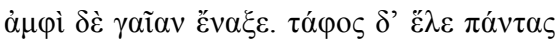

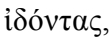

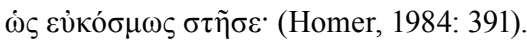

First then he set up the axes, when he had dug a trench, one long trench for all, and made it straight to the line, and about them he stamped in the earth. And amazement seized all who saw him, that he set them out so orderly (Homer, 1919b: 313).

According to the interpretation of $\mathrm{R}$.

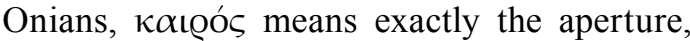
through which the arrow is shoot, whence the meaning of opportunitas ( $\pi$ ó@os, a means of passing) derives.

But if we evoke Homer's Phaeacians we notice that another understanding will be

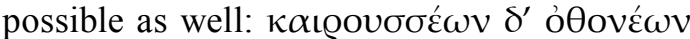

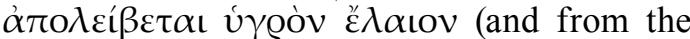
closely-woven linen the soft olive oil drips down). The idea is clear: the more appropriately and tightly the threads of the warp are put into order, the better is the quality of the fabric produced. The distance between the threads of the warp should be minimal or better - optimal. In this case the lesser the dis-

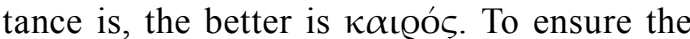
optimal distance between the threads of the warp a special device is wanted, something like a regulating thread, which separates the threads of the warp preventing them from tangling. The threads of the warp are responsible for the length of a fabric, the threads of the weft - for a fabric itself. In other words: the threads of the warp make a fabric possible, the threads of the weft - real and they also account for a design or pattern.

So the fabrics of the Phaeacians give

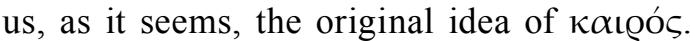
It looks like here for the first time we have

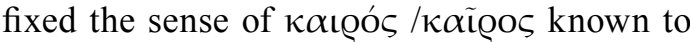
Homer.

Compared to the sense of kaíptos in the military contexts of the Iliad, the passage describing the tissues of the Phaeacians could add to our understanding of the concept in discussion. What this weak spot of the panoply

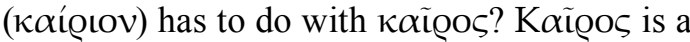
special thread, placed at one edge of a wouldbe tissue, which being interwoven between the threads of the warp secures the order and prevents the threads of the warp from tangling. The role of this regulating thread (supposedly 
$\kappa \alpha \tilde{\mathrm{i}} \mathrm{S})$ ) would be very important taking into account the absence of warp-beams in the structure of the ancient loom: kaĩoos facilitated the process of inserting the filling thread (weft).

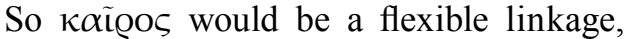
a thread interwoven between the warp which exerts two functions at once: it separates and connects at the same time. To illustrate how it worked we shall cite Homer again (Il. XIX, 384-385):

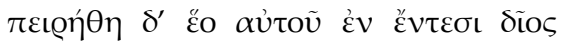
A $\chi \iota \lambda \lambda \varepsilon \dot{s} \varsigma_{,}-$

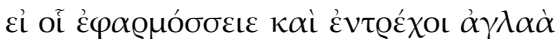

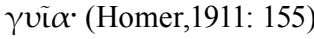

and goodly Achilles made proof of himself in his armour, whether it fitted him, and his glorious limbs moved free (Homer, 192425b: 365).

In order to be efficient in a battle, a warrior needs to feel himself comfortable in his armor. So he secures it with the thongs (e.g. the Dandra panoply as described above), fastens all the pieces of his panoply so that they fit perfectly and protect the vital parts of the body without impeding his movements.

Let us, for example, recall the scene-Hector hits Tuecer's shoulder (Il. VIII, 324 - 328). A glance cast on the armor makes it evident that this part of the cuirass (which protects a shoulder) is most weak and vulnerable because this is just the very spot of ligatures - the cords connecting the plates of a panoply. In other words, this part of the armor would be supplied with a great number of kaĩooses. One could

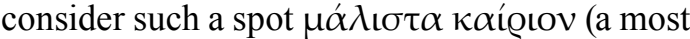
vulnerable). The ligatures of a panoply remind the kaĩoos of the loom.

Let us recapitulate the principal connotations of the word kairos, being interpreted as a

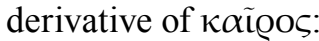

1) as a regulating thread it supposes the idea of control;

2) again as a regulating thread it secures the vertical order of the warp guaranteeing this way the due measure, and as result we produce a tissue of high quality;
3) as an interwoven thread it separates and connects at the same time.

So a kairotic spot should be any part of the panoply, where the ligatures are situated. These cords or thongs should be tight enough in order the cuirass protect the body of a soldier, making apertures minimal, but at the same time they should not impede the movements of a soldier. Briefly, all the cords, ligatures and threads (if we talk about tissues) must be optimal.

Summing up the arguments of this part of our paper, we come to the following conclusion: the concept of kairos suggests a set of elements, which constitute this phenomenon. It means that kairos should not be interpreted as a moment, an opportunity et cetera. It should rather designate a complex structure, including a set of elements with an ambiguous connotation, such as, for example, opportunity/inopportuneness, a right moment/a wrong moment. Such an interpretation is rooted in the notion of kairos as it has been construed above.

As a set of elements and constituent parts involving the phenomenon of time, kairos can be reconsidered within a special context - the context of narration and composition. We possess textual evidences in the Greek lyrics, which could serve us to corroborate this hypothesis. So we turn to the poetry of Pindar (522/18-448/438).

In the Victory Odes of Pindar there is a lot of words and expressions which have obvious reference to the art of weaving. This metaphorical transference of the notions, directly connected to the concrete art of weaving, to the domain of poetry is quite legitimate. Let

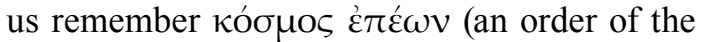
words). We have a similar image in Homer's $\mathrm{Il}$ -

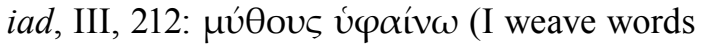
or discourse), or very close semantically $\pi \lambda \varepsilon ́ \kappa \varepsilon ı v ~ \lambda o ́ \gamma o u s$ (interweave words), which, for that matter, hints at a complex composition of Aristotle, that is his $\alpha \pi \lambda$ oi $\mu \tilde{v} \theta$ or (simple plots)/ $\pi \varepsilon \pi \lambda \varepsilon \gamma \mu \varepsilon \dot{v}$ or $\mu \tilde{v} \theta$ ot (complex plots).

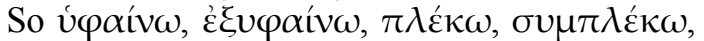

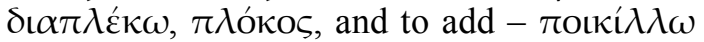
with an adjective $\pi$ oukí $\lambda$ os - belong to the semantic group which fixes different shades of the art which has to do with threads. Not 
to leave it unsubstantiated, we quote Pindar (Olympic I, 8-9):

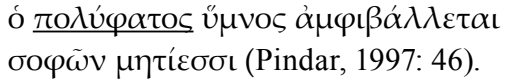

The famous hymn is embraced by the wisdom of wise men (Pindar, 1997: 47)

[The translation is ours. - E.A.]

This passage is interesting because of a pun on words, which suggests two meanings because of similarity in sound: $\pi 0 \lambda v ́-\varphi \alpha \tau o \varsigma$ (famous) and $\pi 0 \lambda$-v́ $\varphi \alpha \tau o \varsigma$, the second part of which sounds to the Greek ear as if it were a

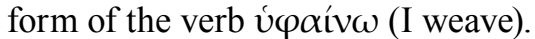

We shall not exaggerate quoting. A close reading of Pindar's contexts evoking the art of weaving, leads us to understand that this art is intimately connected with the art of poetic

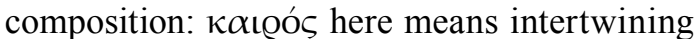
of themes, ingenious composition, ability to unite a multitude into a comprehensible unity. The wise are those who are capable to understand this complexity. And the complexity itself evolves in time and through time. This articulation of elements and the relevant composition have discursive and thus temporal nature. The same nature reveals itself in the phenomenon of a literary composition (plot) and dialogue.

The royal art of weaving. Now we turn to the dialogue as a philosophical genre. It originates in the practice of sophistic agon logon (competition of discourses) and the practice of Greek drama. In the circle of the so-called Socratics this form of discourse was very popular (Alymova, 2017b: 97-116).

Panatios in the famous doxographic book of Diogenes Laertius (DL II, 64) (Diogenes Laertius, 2008: 136) names six authors of Socratic dialogues: Antisthenes, Aeschines, Pheado, Eucleides, Xenophon and Plato. The Socratic writings originated in a narrow circle of close disciples of Socrates. As a genre the Socratic dialogue is a collective production. It flourished between 390 and $350 \mathrm{BCE}$.

We have already discussed the problem of origin of the Socratic dialogue (Alymova, 2017b: 97-116), so we will not go into details here. Hereby we would like to emphasize one aspect. A great contribution to the configuration of the Socratic dialogue was made by the Sophists (Alymova, 2015: 23 - 29). They not only initiated the practices of contest of speeches ( $\left.\dot{\alpha} \gamma \tilde{\omega} v \varepsilon \varsigma \lambda{ }^{\prime} \gamma \omega v\right)$, but also influenced Socrates (who once pertained to their circle) and his disciples (some of them, e.g. Antisthenes, had been pupils of the Sophists). Given the attitude of the Sophists towards the problem of (im)possibility to render and express the knowledge of the reality, we must admit that for the Sophists the dialogue was a natural and consequential form of educational (and philosophical) discourse. Within the circle of the Sophists the concept of kairos gained a special slant: this concept presented itself as multilateral and three-dimensional (at least). It means they elaborated a special way of communication between the teacher and his audience which was based on recognition of detachment of the subject of cognition from the world itself as it is and of dramatic role of language in communication of any experience of the world. In such circumstances a monologue of a teacher meant nothing: it would not convey any precise knowledge - the only possible way of communication was dialogue (according to special rules, or technics) which involved different interlocutors lead by a teacher. They were in search of a convincing truth. That is why the skills in rhetoric had such a significant role. One might say without exaggeration that the teacher and his pupils were engaged in the process of weaving a mutual context. In other words, they created a situation of communication where common concepts might be brought to light. We call this situation kairotic.

And now we concentrate our attention on an exemplar version of this genre - that is on the Socratic dialogue as represented by Plato.

The genre of philosophical dialogue demonstrates traits similar to the art of weaving: a composition, intertwining and interweaving of words, which constitute a network.

In the writings of Plato we encounter not only the form of dialogue as such, but also an intuition (and most probably - understanding) of suggestive power of the dialogue as a philosophical way to involve interlocutors (and readers as well - and this is of great import) 
into a certain procedure which could lead them (sometimes via perplexity) to gather that the life of mind and reason is complicated and that philosophizing is a perpetual exercise and exertion, the aim of which is to make them (and us) perceive the Good and thus actualize the pursuit of happiness.

To this general consideration we should add another one which takes into account the figure of the ruler, of a politician. According to Plato's Republic (and The Laws) the ruler of a polis should be philosopher, in other words a person who understands the essence of the Good. The ruler knows how to combine all the necessary constituent elements in order to create the best possible political regime. To illustrate how it should work, Plato uses a metaphor which became a topos in the Greek literature - the metaphor of ship. Let us cite the relevant context (the Athenian touches the problems concerning the dissolution of a polity, Leg. c3-d1):

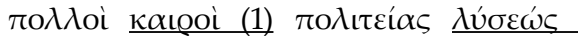

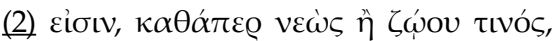

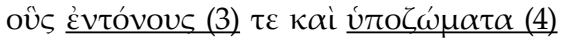

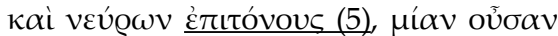

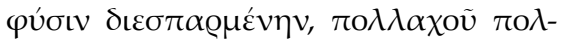

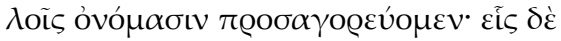

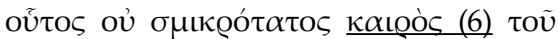

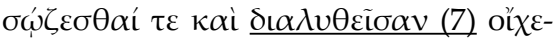

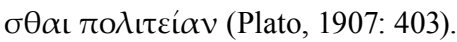

"In fact, the case stands thus: - The dissolution (2) of a polity, like that of a ship's frame, depends upon many critical factors (1): these (in the case of a ship) though one in nature are separated into many parts, and we call them by many names-such as stays (3), under-girders (4), bracing-ropes (5). For the preservation, or dissolution (7) and disappearance, of a polity the office of examiner is such a critical factor (6), and that of the gravest kind" (Plato, 1926: 487, 489).

It is but accurate: kairos is translated here as "critical factors". Meanwhile the picture and the metaphor itself become more clear and appear in full light with all possible connotations if we interpret them in the terms of kairos as it has been demonstrated above, that is in the terms of the art of weaving. The vocabulary,

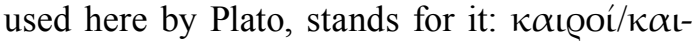
oós is a keyword of the context is surrounded by words which imply threads or cords: $\lambda u ́ \sigma \iota \varsigma$ (dissolution, also used to describe the process of taking off the armor of a soldier), हैvotvos (stay, a strong rope used to support a mast),

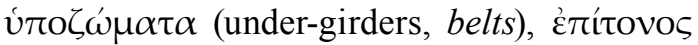
(bracing-ropes).

Moreover, it looks like Plato himself supports this reading. To corroborate this thesis we adduce another context - The Statesman (305e sqq). Plato paragons the activities of the weaver and the politician. He writes that the art

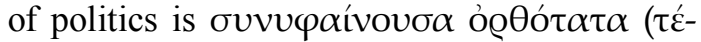
$\chi v \eta)(305 \mathrm{e} s q)$, that is the art of weaving the threads together into one web.

The statesman, according to Plato, should pick up the best, the most appropriate. We shall cite again (not to indulge in citing Greek, we quote here the translation of B. Jowett):

STRANGER: But the science which is over them all, and has charge of the laws, and of all matters affecting the State, and truly weaves them all into one, if we would describe under a name characteristic of their common nature, most deservedly we may call politics.

YOUNG SOCRATES: Exactly so.

STRANGER: Then, now that we have discovered the various classes in a State, shall I analyze politics after the pattern which weaving supplied?

YOUNG SOCRATES: I greatly wish that you would.

STRANGER: Then I must describe the nature of the royal web, and show how the various threads are woven into one piece. (...)

STRANGER: Then the true and natural art of statesmanship will never allow any State to be formed by a combination of good and bad men, if this can be avoided; but will begin by testing human natures in play, and after testing them, will entrust them to proper teachers who are the ministers of her purposes - she will herself give orders, and maintain authority; just as the art of weaving continually gives orders and maintains authority over the carders and all the others who prepare the material for the work, commanding the subsidiary arts to execute the 
works which she deems necessary for making the web.

STRANGER: In like manner, the royal science appears to me to be the mistress of all lawful educators and instructors, and having this queenly power, will not permit them to train men in what will produce characters unsuited to the political constitution which she desires to create, but only in what will produce such as are suitable. Those which have no share of manliness and temperance, or any other virtuous inclination, and, from the necessity of an evil nature, are violently carried away to godlessness and insolence and injustice, she gets rid of by death and exile, and punishes them with the greatest of disgraces.

YOUNG SOCRATES: That is commonly said. (...)

STRANGER: The rest of the citizens, out of whom, if they have education, something noble may be made, and who are capable of being united by the statesman, the kingly art blends and weaves together; taking on the one hand those whose natures tend rather to courage, which is the stronger element and may be regarded as the warp, and on the other hand those which incline to order and gentleness, and which are represented in the figure as spun thick and soft, after the manner of the woof these, which are naturally opposed, she seeks to bind and weave together in the following manner.

YOUNG SOCRATES: In what manner?

STRANGER: First of all, she takes the eternal element of the soul and binds it with a divine cord, to which it is akin, and then the animal nature, and binds that with human cords. (...)

STRANGER: This then we declare to be the completion of the web of political action, which is created by a direct intertexture of the brave and temperate natures, whenever the royal science has drawn the two minds into communion with one another by unanimity and friendship, and having perfected the noblest and best of all the webs which political life admits, and enfolding therein all other inhabitants of cities, whether slaves or freemen, binds them in one fabric and governs and presides over them, and, in so far as to be happy is vouch- safed to a city, in no particular fails to secure their happiness.

YOUNG SOCRATES: Your picture, Stranger, of the king and statesman, no less than of the Sophist, is quite perfect. (Plato, 1892: 523-530).

We have cited this context at length and underlined the words, pertinent to our explication, because it demonstrates the significance of the image of weaver and the art of weaving (called here royal) as a paradigm in Plato's philosophical discourse.

Until this moment we have considered the Poet (epic and lyric), the Sophist, the Politician as representatives of the art of weaving - the art of creating kairos. Now, taking into account Plato's dialogue The Sophist, we arrive at a crucial point (Plato, 1995: 401): chasing the sophist, the interlocutors develop a special procedure to attain an accurate result. They practice a method of strict distinguishing, which they compare in particular to the art of carding yarn

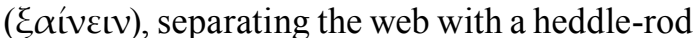

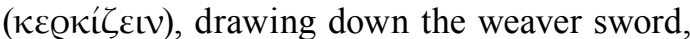
whose function is to beat the weft against the

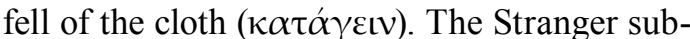
sumes all these procedures, which constitute the art of weaver, under the art of separation

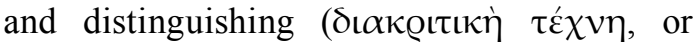

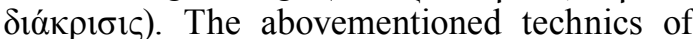
separating yarn and threads serve to distinguish the better from the worse, the similar from the dissimilar. So the Stranger concludes that all the arts of distinguishing must be designated as purification ( $\kappa \alpha \theta \alpha \varrho \mu$ ó $\tau \tau \varsigma)$.

The masters of the same art - the art making fabric (in metaphorical sense, of course) are philosophers, because they should be versed in the art of "yarning" and "weaving" concepts

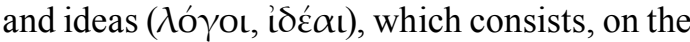
one hand, in separating the right concept from the wrong one and, on the other - in interweaving the right ones, arranging them in the best possible order, or, if we put it another way, Plato holds the royal art of weaving for a paradigm of dialectics.

Cosmos and Polis are tissues, (con)texts created by Gods and wise men. In the perspective of a philosophical discourse the dialogue, being a context as well, constitutes, or better - 
should constitute, a situation, which we, taking into account our analysis, call kairotic, that is a situation which involves not only the interlocutors as protagonists of a dialogue, but the reader as well. The reader is exactly the point where all the semantic lines encounter: he/she is the crucial point of any philosophical dialogue, the point where the meaning conveyed/intended comes to actuality.

\section{Conclusions}

We have undertaken a sort of archeological research not to destroy the tradition, but in order to reconsider it. We think that the interpretation of B. Gallet (Gallet, 1990) makes it possible to explain all the traditional meanings of kairos and even adds to them. This interpretation lets us reconsider the concept of kairos in a wider perspective and even introduce a new formula - kairotic situation or kairotic logos (as applied specifically to a philosophical discourse). Kairotic situation is a combination or conjuncture of elements. It involves 1) the author (an authoritative instance, responsible for creation of such a situation), who composes all the elements, 2) the narrator or protagonist, 3) his audience and interlocutors, and 4) the reader, or an extradiegetic audience, a witness of the drama of a dialogue. The realization of kairos depends on communication of these elements, on their intertwining, on their being interwoven one with another in the best possible way. Kairotic situation/kairotic logos is created by an author: poet (epic, lyric or dramatic), rhetorician (a Sophist), politician, and philosopher, such as Plato, philosopher and dramatist.

\section{References}

Alymova, E.V. (2008). Mimeticheskoe nachalo pojeticheskogo iskusstva [Mimetic origin of poetic art]. In Antichnyj mimesis. Sbornik statej, posvjashhennyj pamjati professora Konstantina Andreevicha Sergeeva [Ancient mimesis. Papers in honor of professor Konstantin Andreevich Sergeev], 8-28.

Alymova, E.V. (2015). Oderzhal li Sokrat pobedu nad Protagorom, ili agon logon v dialoge "Protagor" [Did Socrates get the upper hand on Protagoras or agon logon in "Protagoras"]. In Tezisy dokladov XXII mezhdunarodnoi konferenzii "Universum platonovskoi mysli": "Korpus textov Platona v istorii ego interpretazii" [Proc. of the $22^{\text {nd }}$ International conference "The universe of Platonic thought": Corpus of Plato's Texts in the History of its Interpretations]. Saint Petersburg, June 24-25. 249 p.

Alymova, E.V. (2017a). Narratsiia i siuzhetoslozhenie kak iznachal'nye formy aktualizatsii kontsepta vremeni $\mathrm{v}$ grecheskoi mysli (nekotorye razmyshleniia $\mathrm{v}$ sviazi s traktovkoi vremeni $\mathrm{v}$ dialogakh Platona) [Narration and plot as initial structures, which actualize the concept of time in Greek thought (some ideas exposed in connection with the treatment of time in the dialogues of Plato)]. In Tezisy dokladov XXV nauchnoi konferenzii "Universum platonovskoi mysli": "Platon I antichnaia nauka" [Proc. of the $25^{\text {th }}$ International conference "The universe of Platonic thought": "Plato and ancient science"]. Saint Petersburg, June 21-22. 169 p.

Alymova, E.V. (2017b). Jeshin iz Sfetta i tradicija sokraticheskogo dialoga [Aeschines of Sphettus and the tradition of the Socratic dialogue]. In Platonovskie issledovanija [Platonic Investigations], 7 (2). P. 97-116.

Chantraine, P. (1968-1980). Dictionnaire étymologique de la langue grecque. Histoire des mots. Paris, Éditions Klincksieck, 1368 p.

Diogenes Laertius (2008). Vitae philosophorum. Berolini et Novi Eboraci, Walter de Gruyter, 826 p.

Frisk, H. (1960). Griechisches Etymologisches Wörterbuch. In 2 Bde. Heidelberg, Carl Winter Universitätsverlag, Bd. 1,938 p.

Gallet, B. (1990). Recherches sur kairos et l'ambiguïté dans la poésie de Pindar. Lille, Presse universitaire de Lille III, $404 \mathrm{p}$.

Hesiod (1878). Erga kai hemerai. In Hesiodi Quae feruntur carmina. Lipsiae, aedibus B.G. Teubneri, 56-87. Hippocrates (1923). Precepts. In Hippocrates. In 8 vol. London, William Heinemann Ltd., Cambridge, MA, Harvard University Press, 1, $303-332$.

Homer (1910). Ilias, In 2 parts. Lipsiae, In aedibus B.G. Teubneri, Part 1, 249 p.

Homer (1911). Ilias, In 2 parts. Lipsiae, In aedibus B.G. Teubneri, Part 2, 264 p.

Homer (1984). Odyssea. Stutgardiae, Teubneri, 469 p. 
Homer (1924-25a). The Iliad, In 2 vol. London, William Heinemann; New York, G.P. Putnam's Sons, Vol. 1, $614 \mathrm{p}$.

Homer (1924-25b). The Iliad, In 2 vol. London, William Heinemann; New York, G.P. Putnam's Sons, Vol. 2, $668 \mathrm{p}$.

Homer (1919a). The Odyssey. In 2 vol. Cambridge, MA, Harvard University Press; London, William Heinemann Ltd., Vol. 1, 499 p.

Homer (1919b). The Odyssey. In 2 vol. Cambridge, MA, Harvard University Press; London, William Heinemann Ltd., Vol. 2, 478 p.

Jampolsky, M. (2007). Tkach i vizioner. Ocherki istorii reperezentacii, ili O material'nom i ideal'nom $v$ kul'ture [Weaver and visionary. Essays on a history of representation or About material and ideal in culture]. Moscow, Novoe literaturnoe obozrenie, $610 \mathrm{p}$.

Onians, R.B. (1951). KAIROS. In Onians R.B. The Origins of European Thought: About the Body, the Mind, the Soul, the World, Time and Fate: New Interpretations of Greek, Roman and kindred evidence also of some basic Jewish and Christian beliefs. Cambridge, Cambridge University Press, 583 p.

Pindar (1947). Carmina cum fragmentis. Oxonii, E typographeo clarendoniano, $291 \mathrm{p}$.

Pindar (1997). Olympian Odes. Pythian Odes. Cambridge, MA; Harvard University Press. 386 p.

Plato (1907). Leges. In Platonis Opera. In 5 vol. Oxford, E typographeo clarendoniano, Vol. 5, 14-436.

Plato (1926). Laws, In 2 vol. London, William Heinemann; New York, G.P. Putnam's Sons, Vol. 2, 596 p.

Plato (1995a). Sophista. In Platonis Opera. In 5 vol. Oxford, E typographeo clarendoniano. Vol. 1, 383-471.

Plato (1995b). Politicus. In Platonis Opera. In 5 vol. Oxford, E typographeo clarendoniano. Vol. 1, 473-559.

Plato (1892). Statesman. In The Dialogues of Plato. In 4 vol. Oxford, At the Clarendon Press, Vol. 3, 429530 .

Trédé-Boulmer, M. (2015). Kairos. L'à propos et l'occasion. Le mot et la notion, d'Homer à la fin du IVe siècle avant J.-C. Paris, Les Belles Lettres, $361 \mathrm{p}$. 


\title{
Сократический диалог как кайротический логос
}

\author{
Е.В.Алымова \\ Санкт-Петербургский государственный университет \\ Российская Федеращия, Санкт-Петербург
}

\begin{abstract}
Аннотация. Статья посвящена сократическому диалогу как жанру античной философской прозы, представителями которой были ученики Сократа - так называемые сократики. Шедеврами этого жанра являются диалоги Платона. Оригинальность данного исследования заключается в том, что сократический диалог рассмотрен в свете одного из самых загадочных концептов античной философии, каковым выступает кайрос. Встречаясь весьма часто в различных контекстах (как в поэтических, так и в прозаических), он нигде не получает определения, зато спектр его толкований велик. Свидетельство этому мы обнаруживаем в том числе и в переводах: мера, удобный случай, возможность, обстоятельства, кризис, цель, подходящее время, «свой час» (М.Л. Гаспаров), «пора» (В.В. Бибихин, А.В. Ахутин), и этот ряд можно продолжить. Здесь термин подвергается реинтерпретации, в основании которой изначальная связь кайроса с искусством ткачества, которое, в свою очередь, предстает как парадигма для искусства плетения логосов и драматического сюжетосложения.
\end{abstract}

Ключевые слова: кайрос, логос, сократический диалог, философский диалог, сократики, искусство ткачества, Платон.

Исследование Socratic Dialogue as Kairotic Logos (Сократический диалог как кайротический логос) выполнено при финансовой поддержке РФФИ по проекту № 17-03-00616-ОГН а: «Сократические школы как явление античной философии и культуры». 2017-2019.

Научная специальность: 09.00.00 - философские науки. 